DOI: https://doi.org/10.15407/techned2019.05.021

\title{
INVESTIGATION OF MAGNETIC-CONNECTED INDUCTANCES BY SIGNAL GRAPHS
}

$\quad$ Journal
Publisher
ISSN
Issue
Pages

Tekhnichna elektrodynamika Institute of Electrodynamics National Academy of Science of Ukraine 1607-7970 (print), 2218-1903 (online) No 5, 2019 (September/Oktober) $21-26$

\author{
Authors \\ V.G. Yagup*, K.V. Yagup** \\ Kharkiv National University of Municipal Economy, \\ Marshala Bazhanova str., 17, Kharkov, 61002, Ukraine, \\ e-mail: yagup.walery@gmail.com \\ * ORCID ID : http://orcid.org/0000-0002-7019-3499 \\ ** ORCID ID : http://orcid.org/0000-0002-9305-8169
}

\begin{abstract}
The article conciders a description of a system of magnetically coupled inductances using signal graphs. Equivalent transformations of the signal graph allowed to present it in the form when the nodal signals of currents and voltages are expressed through three parameters: inductance of the primary winding and coupling and transformation factors. Mathematical dependencies for the leakage inductance and the relationship between the primary side leakage inductance and the secondary side inductance are obtained. An analysis of these relationships shows that with a decrease in the coupling factor, the fraction of the reduced leakage inductance of the secondary winding increases nonlinearly, and a uniform distribution of the leakage inductance between the primary and secondary sides is possible only for coupling factor, which is close to unity. On the basis of the carried out research, the possibility of neglecting the mutual influence of three-phase transformer windings located on different it's rods. References 9, figures 8.
\end{abstract}

Key words: magnetically coupled inductances, signal graph, coupling factor, leakage inductance. 
Received: 29.11.2018

Accepted: 29.05.2019

Published: 01.08.2019

\section{References}

1. Voldek A.I., Popov V.V. Electric machines. Introduction to electrical engineering. DC machines and transformers. S-Pb.: Piter, 2008. 320 p. (Rus)

2. Rozanov Yu.K., Ryabchinsky M.V., Kvasnyuk A.A. Power electronics. Moskva: MEl, 2009. 632 p. (Rus)

3. Mesyats G.A. Generation of powerful nanosecond pulses. Moskva: Sovetskoe radio, 1974. 256 p. (Rus)

4. Ryskova Z.A., Fedorov P.D., Zhimereva V.I. Transformers for electrical resistance welding. Leningrad: Energoatomizdat, 1990. 424 p. (Rus)

5. Pentegov I.V., Rymar S.V., Volkov I.V. Relationship between the parameters of electromagnetic, circuit diagrams and equivalent circuits of double-winding transformers. Electri cal engineering \& Electromechanics

. 2006. No 3. Pp. 67-79. (Rus)

6. Mason S.J., Zimmerman H.J. Electronic Circuits, Signals, and Systems. New York: Hardcover, 1960. 620 p.

7. Chernykh I.V. Modeling of electrical devices in Matlab, SimPowerSystems and Simulink. DMK: Press, 2011. 288 p. (Rus)

8. Yagup V.G. Methodology of computer simulation of thyristor converters based on signal graphs. Vestnik nauki i tekhniki. 2002. Vol. 6. Pp. 4-7. (Rus)

9. Yagup V.G., Yagup K.V. Computer simulation of transient and steady-state processes in electrical energy converters. Kharkov: HNAGH, 2013. 131 p. (Rus) 